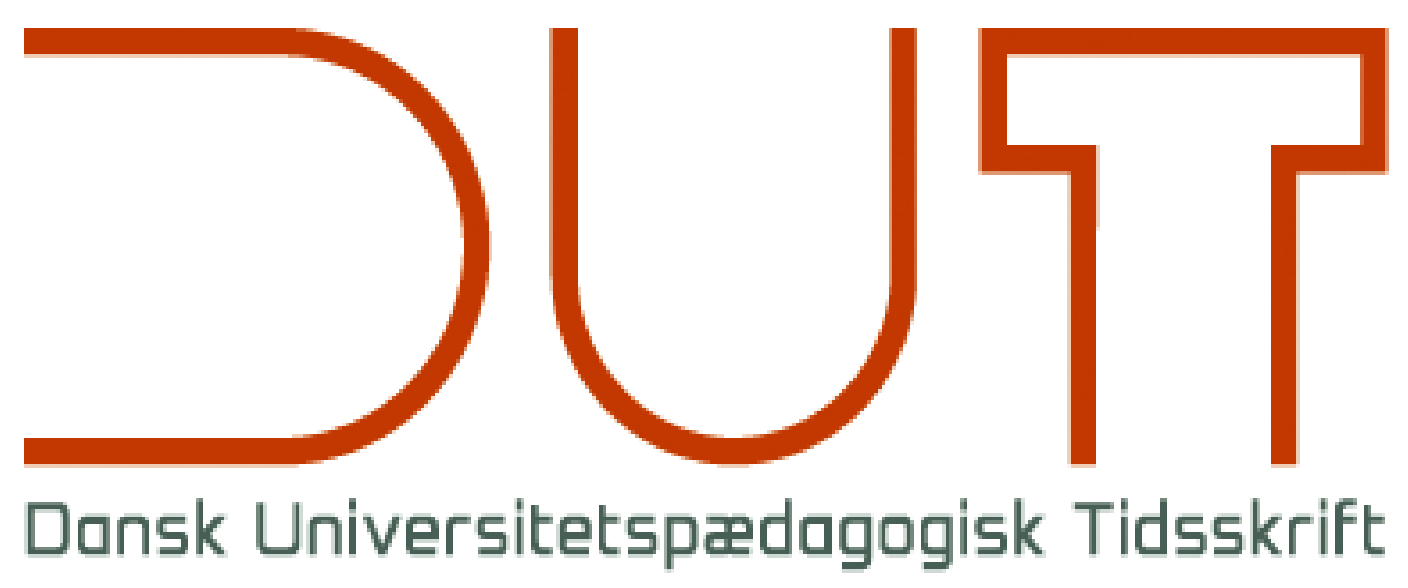

Læringsrum

Årgang 14 nr. 27 / 2019

Titel

Succeskriterier for anvendelse af Business Intelligence i universitetssektoren

Forfattere

Sidetal

Rikke Gaardboe, Tom Nyvang, Erling Jensen

$50-65$

Udgivet af

Dansk Universitetspædagogisk Netværk, DUN

URL

> http://dun-net.dk/

Betingelser for brug af denne artikel

(c) Copyright
Denne artikel er omfattet af ophavsretsloven, og der må citeres fra den. Følgende betingelser skal dog være opfyldt:

- Citatet skal være i overensstemmelse med "god skik"

- Der må kun citeres „i det omfang, som betinges af formålet“

- Ophavsmanden til teksten skal krediteres, og kilden skal angives ift. ovenstående bibliografiske oplysninger.

DUT og artiklens forfatter 


\title{
Succeskriterier for anvendelse af Business Intelligence i universitetssektoren
}

\author{
Rikke Gaardboe ${ }^{\mathrm{a}, 1}$, Tom Nyvang ${ }^{\mathrm{b}}$, Erling Jensen ${ }^{\mathrm{c}}$ \\ anstitut for Statskundskab, Aalborg Universitet, bInstitut for Kommunikation, Aalborg Universitet \\ 'Institut for Økonomi og Ledelse, Aalborg Universitet
}

Videnskabelig artikel, fagfællebedømt

\begin{abstract}
Gennem de sidste 10-15 år har universitetssektoren i Danmark undergået en række reformer og forandringer. En konsekvens heraf er et behov for højere grad af styring, som blandt andet understøttes af Business Intelligence (BI). BI er et begreb, der beskriver teknologier, software og processer til at tilvejebringe og analysere data til brug for beslutningstagning. I denne artikel undersøges, hvordan universiteter kan opnå succes med Bl, samt hvilken organisatorisk nytte teknologien har. Studiet viser, at jo højere systemkvalitet, des højere brugertilfredshed og mere brug af BI. Øget informationskvalitet påvirker brugertilfredsheden. Den individuelle nytte af BI påvirkes af brugertilfredshed og brug. Der opnås organisatorisk nytte ved at anvende BI til rapportering, til ad hoc-analyser samt til opfølgning på forløb. Til trods for at teknologien kan anvendes til learning analytics, er det ikke med det formål, teknologien er implementeret, men mere i relation til nøgletal for økonomisk rapportering og kvalitetsmålinger.
\end{abstract}

\section{Introduktion}

Universitetssektoren i Danmark har i de sidste 10-15 år gennemgået en række reformer og forandringer. Først er antallet af studerende steget markant med afsæt i en politisk målsætning om, at flere skulle have en lang videregående uddannelse (se fx regeringsgrundlaget fra 2005 (VK Regeringen II, 2005)). Senere er antallet af studerende faldet lidt igen i forbindelse med det øgede politiske fokus på dimittendernes beskæftigelsesgrad og den deraf følgende centrale dimensionering af en lang række uddannelser (se for eksempel regeringsgrundlaget fra 2015: (Regeringen, 2015). Den såkaldte fremdriftsreform (i forskellige versioner), der er gennemført med henblik på at få de studerende hurtigere gennem uddannelsessystemet, forpligter også universiteterne (og andre) til at monitorere de studerendes studieprogression og til at handle, hvis progressionen er langsommere end forventet (Uddannelses- og Forskningsministeriet, 2018).

I takt med at der kom flere studerende, voksede antallet af ansatte ved universiteterne også, bygningsmassen blev mange steder udvidet osv. I samme periode har vi fået indført et akkrediteringssystem for alle videregående uddannelser i landet. I første omgang var der tale om turnusakkreditering af hver enkelt uddannelse og senere også muligheden for at akkreditere hele institutionen i stedet for hvert enkelt uddannelsesudbud. Parallelt med forandringerne og de nye krav er bevillingen pr. studerende faldet $2 \%$ årligt i en årrække. Det har ændret rammerne for det universitetspædagogiske arbejde. Mange universitetsuddannelser skal således både uddanne billigere, reducere frafald og i mange tilfælde også øge mængden

\footnotetext{
${ }^{1}$ Kontakt: gaardboe@business.aau.dk
} 
af undervisning, mens man følger dimittendernes samfundsmæssige relevans. Hvis det nogensinde har været tilstrækkeligt, at det universitetspædagogiske (og -didaktiske) arbejde forholdt sig snævert til fag, nyeste forskning og de studerendes forudsætninger, så er det i hvert fald ikke tilstrækkeligt længere.

De nye eksterne forandringer og krav har affødt en række nye interne behov på universiteterne og har introduceret et markant fokus på en række nøgletal i planlægningsarbejdet. Mange af disse griber direkte ind i arbejdet med den pædagogiske tilrettelæggelse af universiteternes uddannelser.

Selvom vi ikke tænker meget over det i hverdagen, starter det datadrevne universitetspædagogiske arbejde allerede ved optagelsen af de studerende. I lyset af kravene til fastholdelse og gennemførelse fokuserer universiteterne meget på at få de "rigtige" studerende - det vil sige de studerende, der mest sandsynligt kan færdiggøre uddannelsen på normeret tid. Her analyseres sammenhæng mellem adgangsgivende eksamen, evt. præstation ved optagelsesprøver og præstationer i uddannelsen med henblik på at træffe beslutning om optag af kommende årgange. Når de studerende er kommet ind, fortsætter det. Progressionen monitoreres, og målestokken er normeret studietid. Hvis studerende er forsinkede, skal universitetet sætte ind - særligt i forhold til den enkelte studerende, der skal have hjælp, men ofte også i forhold til at belyse årsagerne til forsinkelsen. Grundantagelsen synes at være, at det i udstrakt grad er universitets ansvar, at de studerende færdiggør uddannelsen på normeret tid.

Data har også fået en meget stor rolle i beslutninger om fordeling af undervisning og undervisere mellem uddannelser og i den enkelte uddannelse. Akkrediteringssystemets udvikling fra turnusakkrediteringer af enkeltuddannelser til de nuværende altomfattende institutionsakkrediteringer har således udløst enorme dokumentationskrav med øgede bestræbelser på at nå frem til relevante indikatorer og nøgletal (KPI'er) for kvaliteten af undervisningen. Forskningsdækning måles blandt andet med VIP/DVIP-ratioer, hvor VIP er det forskningsansatte videnskabelige personale, mens DVIP er de ikke-forskningsansatte deltidsmedarbejdere. Grundantagelsen synes i denne del af akkrediteringssystemet at være, at undervisning varetaget af forskningsansatte er vigtigst. Omfanget af undervisningen måles i form af konfrontationstimetal, der indsamles for alle uddannelser og udstilles på landsplan i "Uddannelseszoom". Her synes grundantagelsen at være, at meget undervisning er bedre end lidt undervisning.

Det sidste nøgletal i et uddannelsesforløb, som universiteterne skal styre efter, er dimittendernes beskæftigelsesgrad. Dimensionering af uddannelserne er således tæt forbundet med måling af dimittendernes beskæftigelsesgrad. Grundantagelsen synes at være, at relevansen af uddannelser måles på dimittendernes beskæftigelse.

Udover de data- og nøgletalsanvendelser vi allerede har nævnt, anvendes data også meget tæt på det universitetspædagogiske arbejde ved fx styring af uddannelsernes økonomi og måling af, om den enkelte uddannelse bidrager positivt eller negativt til institutionens økonomi. De grundantagelser om gode uddannelser og god læring, der synes at ligge bag ovennævnte data- og nøgletal, kan naturligvis analyseres dybere og i høj grad diskuteres, ligesom relevansen af hvert enkelt datapunkt kan problematiseres, men vores ærinde med denne artikel er dog et andet. Vi ønsker således at undersøge, hvad der skal til, for at universitetsansatte og -organisationer oplever succes med et såkaldt Business Intelligence (BI) til dataudtræk og -behandling. 
BI bruges til at give adgang til data, til at aggregere data og i et vist omfang også til at analysere data, som ofte hentes fra underliggende fagsystemer. Hensigten er at understøtte beslutningstagere og opnå beslutningstagning på et relevant databaseret beslutningsgrundlag (Watson \& Wixom, 2007). Der findes forskning, som indikerer, at datadrevne virksomheder skulle præstere bedre end andre (Brynjolfsson m.fl. 2011), ligesom Produktivitetskommissionen i 2014 også konkluderede, at den offentlige sektor kunne opnå gevinster ved bedre dataanvendelse. Nu er et dansk universitet jo ikke en virksomhed i traditionel forstand - langt fra. Produktivitetskommissionen er nok heller ikke den faktor eller enhed, der påvirker det universitetspædagogiske arbejde mest i hverdagen. Som nævnt er det dog allerede en del af hverdagen på danske universiteter, at data danner grundlag for beslutninger og fastlægger helt specifikke forståelser af, hvad der er centralt i det pædagogiske arbejde.

Når vi med denne artikel vil tage skridt til at undersøge, hvad der skal til, for at universitetsansatte og -organisationer oplever succes med $\mathrm{Bl}$, så er det både, fordi forventningerne til data er så store, og fordi der investeres så mange ressourcer i området.

Det er imidlertid også vigtigt at pointere, at evaluering af succes er forskellig for den offentlige og private sektor (Rosacker \& Olson, 2008). IT-infrastrukturen er ofte også mere kompliceret i den offentlige sektor end i den private sektor, men det paradoksale er, at hovedparten af forskningen er foretaget i den private sektor (Tona, Carlsson, \& Eom, 2012).

Vores udgangspunkt er en "IS Success Model" af DeLone og McLean (1992), hvor vi undersøger BI-succes fra et slutbruger-perspektiv. Vores metode er her kvantitativ og survey-baseret. Vi vil også anlægge et organisatorisk perspektiv med henblik på at vurdere BI-succes for organisationen som sådan. Her er vores metode kvalitativ og interview-baseret. Dette metodemix er foretaget under hensyntagen til, at det kan være svært eller umuligt at oversætte individuel brug og tilfredshed knyttet til en teknologi til en vurdering af samme teknologis betydning for organisationen som helhed (Petter, DeLone, \& McLean, 2013).

Den resterende del af artiklen er struktureret som følger: I næste afsnit introduceres forskningsmodellen og de heraf afledte hypoteser. Forskningsdesignet og metoden er præsenteret i afsnit 3. Herefter analyseres de kvantitative og kvalitative resultater. Artiklen afsluttes med en diskussion af forskningsresultaterne og en præsentation af hovedkonklusionerne af undersøgelsen.

\section{Business Intelligence succes}

\section{Hvad er Business Intelligence?}

BI kan forstås ud fra et forretningsmæssigt og teknisk perspektiv (Olszak \& Ziemba, 2012). De tekniske definitioner fokuserer på software, infrastruktur og best practices. I den kontekst bliver BI ofte kategoriseret som:

1. ETL-processer, hvor data bliver transformeret fra kildesystemet til et data warehouse.

2. Data warehouse (DW), som er databaser til at gemme og aggregere data.

3. Analytisk værktøj, som giver brugerne adgang til og mulighed for at analysere og dele informationen gemt i DW.

4. Et præsentationslag, som brugeren kan anvende til tilgang til data fra (Olszak \& Ziemba, 2012). 
Definitioner med et forretningsperspektiv lægger vægt på BI som et koncept og en metode, hvor formålet er at forbedre beslutningstagningsprocessen i organisationer (Chen, 2001) samt at distribuere den rigtige information til de rigtige personer på det rigtige tidspunkt (Nakayama, Olbrich, \& Sutcliffe, 2017). Wixom og Watson (2010) definerer BI som et begreb, der beskriver teknologier, software og processer til at tilvejebringe, gemme, have tilgang til og analysere data, hvor formålet er, at brugerne skal træffe bedre beslutninger. I denne definition ligger der, at hvis BI muliggør bedre beslutningstagning, så vil det påvirke organisationers performance. I litteraturen om BI beskrives det, hvordan BI bidrager til, at organisationer opnår deres mål, som eksempelvis højere nettoresultat, højere produktivitet, forbedret service eller en reduktion i omkostninger (Trieu, 2017). Generelt skal BI betragtes som mere end IT, da definitionen af $\mathrm{BI}$ indeholder tekniske, organisatoriske og individuelle perspektiver. Teknologien muliggør, at brugerne kan træffe bedre beslutninger på baggrund af data, der bliver gjort tilgængelige. På den baggrund er det vigtigt, at der i organisationen sker en adfærdsændring, som dermed påvirker organisationen.

\section{Information Systems Success}

BI er en del af metabegrebet Information Systems. Derfor er det nærliggende at forstå Bl's succes ud fra Information Systems Success. I 1992 publicerede DeLone og McLean "IS Success Model". I et litteraturstudie, hvor 180 artikler blev gennemgået, havde de identificeret over 100 forskellige måder at måle succes på. DeLone og McLean syntetiserede de forskellige målemetoder til en seksfaktor-taksonomi ud fra den diversitet, de havde fundet af definitionerne på IS-succes i de studier, de havde gennemgået (Prybutok, Zhang, \& Ryan, 2008). Modellen er præsenteret i Figur 1.

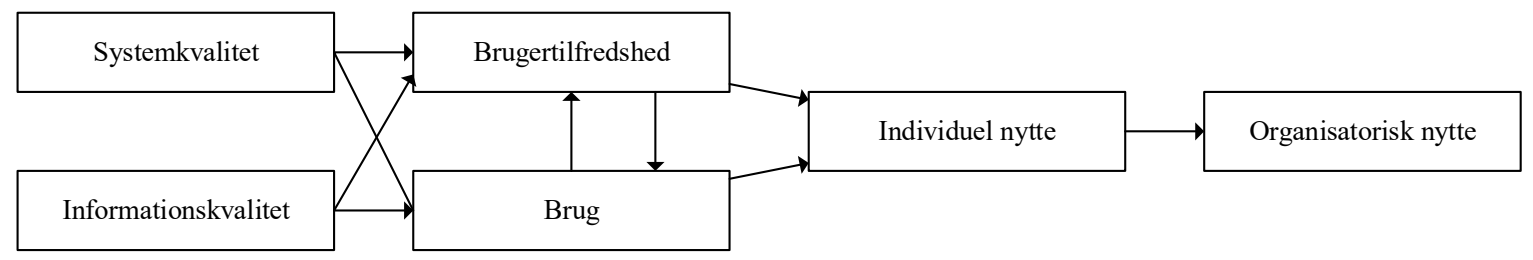

Figur 1. IS Success Model (DeLone \& McLean, 1992, s. 87)

Tanken bag modellen er, at succesfaktorer ikke blot skal forstås ud fra én dimension, men skal forstås ud fra et integreret og omfattende perspektiv. I deres model har de vist, at ISsucces ikke er afhængig af én faktor, men af flere, som er interrelaterede. Modellen i Figur 1 består af seks dimensioner: systemkvalitet, informationskvalitet, brug, brugertilfredshed, individuel nytte og organisatorisk nytte.

Når systemet bliver udviklet, er det karakteriseret ved systemkvalitet og informationssystem. $\mathrm{BI}$ er anvendt af brugere, som i et eller andet omfang er tilfredse med systemet, og gennem brug kan systemet have en individuel nytte og en organisatorisk nytte.

Begrebet systemkvalitet omhandler brugervenligheden af brugergrænsefladen, om brugeren oplever fejl i systemet, samt hvor let systemet er at lære at bruge og at lære (Seddon, 1997). I modellen er også indbygget en anden type af kvalitet: informationskvalitet. Dette begreb refererer til kvaliteten af den information, som BI producerer. Dette er en vigtig faktor, fordi det involverer produktionen af information, der skal bruges i beslutningstagningsprocessen, hvil- 
ket er en væsentlig parameter i forhold til BI (Seddon, 1997). Brug i relation til IS Success Model måles typisk ud fra termer som tid og frekvens. Brugertilfredshed skal forstås som summen af ens følelser og holdninger til en række faktorer, der påvirker denne situation (Bailey \& Pearson, 1983). Individuel nytte er en indikation på, om informationssystemet har givet brugeren en højere produktivitet eller en ændring i brugerens aktivitet (DeLone \& McLean, 1992).

Den afhængige variabel organisatorisk nytte skal forstås som effekten af information på organisationens performance (DeLone \& McLean, 1992). Flere studier har vist, at det kan være vanskeligt at evaluere omkostninger og fordele ved informationssystemer, fordi det ikke altid udtrykkes i monetære termer (Pattavina, 2005). Desuden kan brugeren, som anvender systemet, ikke altid se, hvilken organisatorisk nytte BI-systemet har, da systembrugeren i nogle tilfælde er adskilt fra beslutningstageren (Petter, DeLone, \& McLean, 2008). Desuden måles individuel nytte og organisatorisk nytte på to forskellige niveauer; et individniveau og et organisatorisk niveau. På den baggrund har vi valgt at måle de faktorer, som skaber individuel nytte på brugerniveau, ved hjælp af kvantitativ metode, mens vi identificerer den organisatoriske nytte ved hjælp af kvalitativ metode.

På den baggrund opstilles nedenstående forskningsmodel, som anvendes i denne artikel.

Kvantitativt studie

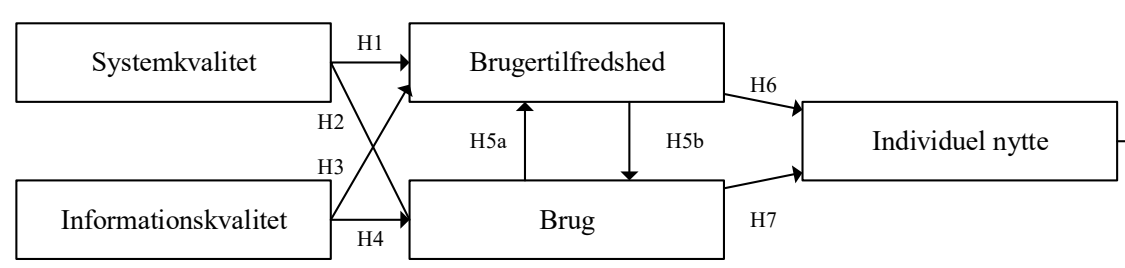

Kvalitativt studie

Organisatorisk nytte

Figur 2. Forskningsmodel og hypoteser, som skal testes

\section{Metode}

Forskningsmodellen er blevet testet og undersøgt i forhold til Bl-brugere på et dansk universitet, der anvender BI-systemet Qlikview fra firmaet Qlik. Qlikview har været anvendt i mere end fem år, så der er altså langt fra tale om nogen ny implementering og ibrugtagning. I den aktuelle organisation bruges BI på alle niveauer af brugere, der har behov for at kunne tilgå data med henblik på analyse og/eller rapportering. Bl-systemet trækker også i det aktuelle tilfælde data fra en række underliggende fagsystemer, så Bl-systemet har også et ekstra præsentationslag (til datatræk) fra underliggende systemer til studieadministration og økonomistyring. Begge dele er i bred forstand, da Bl-systemet for eksempel kan vise bestandstal, ansøgningstal, nøgletal vedrørende bemanding af uddannelser, uddannelsers karakterstatistikker og beskæftigelsessituation. Der tilføjes løbende nye datakilder og præsentationsmuligheder.

Brugerne af Bl-systemet er således både ledere på flere niveauer, personer med ledelsesstøtte som arbejdsområde og personer, som varetager koordinatorfunktioner i den daglige drift og i den forbindelse benytter for eksempel nøgletal om forskningsdækning af en uddannelse, holdstørrelser eller frafaldsstatistikker i planlægning og prioritering af opgaver og 
indsatser. Det betyder samlet set, at stort set alle personalegrupper og funktioner på universitetet er repræsenteret i kredsen af brugere: alle dele af ledelsen, videnskabeligt personale med særlige opgaver (herunder studieledere, studienævnsformænd, studiekoordinatorer) samt stort set alle typer af teknisk og administrativt personale helt ned til den nyansatte kontorelev. Da Bl-systemet giver adgang til forskellige typer af personfølsomme data og data, der af andre grunde er belagt med fortrolighed, styres det via adgangskontrollen, hvilke data den enkelte bruger har adgang til.

Vi har i dataindsamlingen fokuseret på slutbrugerne af Bl-systemet. Det giver os data om anvendelsen af BI-systemet, og vi er bevidste om, at der kan være brugere, som primært trækker data til andres anvendelse og derfor kan have svært ved at vurdere kvalitet og relevans af data mv.

Forskningsdesignet består af et spørgeskema efterfulgt af semi-strukturerede interviews.

\section{Kvantitativ dataindsamling}

For at undersøge de kritiske succesfaktorer for Bl's succes anvendte vi et spørgeskema (Choudrie, 2005; Rai, Lang, \& Welker, 2002). I vores undersøgelse indgik, som nævnt, brugere af $\mathrm{BI}$ på alle niveauer i organisationen, både fra strategisk, taktisk og operationelt niveau. Brugerne af BI anvendte værktøjet til at rapportere, udarbejde forskellige typer af analyser og afstemme data mod kildesystemerne. Brugerne udvælger data og præsenterer det ved hjælp af tabeller eller grafer. Dette kan være på et aggregeret niveau, men det er også muligt at gøre på et detaljeret niveau.

I forbindelse med konstruktionen af spørgeskemaet blev der taget udgangspunkt i en litteraturgennemgang, som identificerer de kritiske succesfaktorer for informationssystemer og Bl-succes (Gaardboe, 2018; Petter m.fl., 2013). Alle artikler i den pågældende litteraturgennemgang blev gennemgået, og alle spørgsmål, som kunne måle en variabel - eksempelvis systemkvalitet - blev skrevet op. Herefter blev de kategoriseret og gennemgået af tre forskere inden for feltet. Dette resulterede i et spørgeskema, der blev udsendt til BI-brugerne i organisationen. Spørgeskemaet kan ses i (Gaardboe, 2018).

Vores dataindsamling blev guidet af Dillmann m.fl. (2014). De udvalgte brugere til deltagelse i undersøgelsen var alle slutbrugere af BI. De modtog en mail med beskrivelse af undersøgelsen samt et link til at deltage. Såfremt brugerne ikke havde deltaget i undersøgelsen efter 14 dage, blev der fulgt op med en påmindelse. Svarprocenten var på 50,7 \%. 540 brugere blev spurgt, om de ville deltage. 344 svarede på undersøgelsen, og ud af dem brugte 274 BI. Efter dataindsamlingens afslutning udførte vi en test for "non-response bias" ved at dele respondenterne i to grupper: en gruppe af respondenter, som havde svaret tidligt i forløbet, og en gruppe, som svarede sent i forløbet. Årsagen er, at de respondenter, som svarer senere, mere ligner de respondenter, der vælger ikke at svare. Vi kunne konkludere, at der ikke var en signifikant forskel mellem de to grupper.

Forskningsmodellen blev testet ved at anvende en strukturel ligningsmodel, som benævnes Partial Least Squares (PLS). Hypoteserne i forskningsmodellen i Figur 2 blev testet med softwaren SMARTPLS 3.2.7. Før modellen kan testes, skal dataenes reliabilitet og validitet vurderes (Fornell \& Larcker, 1981). I denne undersøgelse anvendte vi guidelines fra Hair et. al (2017). I denne guideline vurderes 'outer loading', Cronbach's Alpha, 'composite reliability' og 'AVE'. Grænseværdierne for hver enkelt test er angivet i Tabel 1. 
Tabel 1. Test for validitet og reliabilitet

\begin{tabular}{|c|c|c|c|c|c|}
\hline & & $\begin{array}{l}\text { Outer } \\
\text { loading }\end{array}$ & $\begin{array}{l}\text { Cronbach's } \\
\text { Alpha }\end{array}$ & $\begin{array}{l}\text { Composite } \\
\text { Reliability }\end{array}$ & $\begin{array}{l}\text { Average } \\
\text { Variance } \\
\text { Extracted }\end{array}$ \\
\hline Variabel & ID & $>0,7$ & $>0,7$ & $>0,7$ & $>0,5$ \\
\hline \multirow[t]{3}{*}{ Individuel nytte } & Indlmp01 & 0,911 & \multirow[t]{3}{*}{0,835} & \multirow[t]{3}{*}{0,901} & \multirow[t]{3}{*}{0,754} \\
\hline & IndImp02 & 0,913 & & & \\
\hline & Indlmp03 & 0,774 & & & \\
\hline \multirow[t]{3}{*}{ Informationskvalitet } & InfQua01 & 0,734 & \multirow[t]{3}{*}{0,706} & \multirow[t]{3}{*}{0,836} & \multirow[t]{3}{*}{0,630} \\
\hline & InfQua02 & 0,870 & & & \\
\hline & InfQua03 & 0,772 & & & \\
\hline \multirow[t]{3}{*}{ Systemkvalitet } & SysQua03 & 0,900 & \multirow[t]{3}{*}{0,876} & \multirow[t]{3}{*}{0,924} & \multirow[t]{3}{*}{0,803} \\
\hline & SysQua04 & 0,940 & & & \\
\hline & SysQua05 & 0,845 & & & \\
\hline Brug & Use01 & 1,000 & & & \\
\hline \multirow[t]{3}{*}{ Brugertilfredshed } & UserSat01 & 0,879 & \multirow[t]{3}{*}{0,887} & \multirow[t]{3}{*}{0,930} & \multirow[t]{3}{*}{0,816} \\
\hline & UserSat02 & 0,906 & & & \\
\hline & UserSat03 & 0,924 & & & \\
\hline
\end{tabular}

På baggrund af data i tabel 1 kan det konkluderes, at de indsamlede data har en høj reliabilitet og validitet. Derfor kan de anvendes til videre beregning i PLS.

\section{Kvalitativ dataindsamling}

Den anden del af dataindsamlingen involverede et kvalitativt studie, hvis formål var at opnå mere kontekstuel information for at forstå den organisatoriske nytte af BI-systemer. I dette studie blev Bl-brugerne interviewet. Interviews er et godt supplement til den kvantitative analyse af tre årsager. For det første er interviewdata bedre til at forstå konteksten for brug og nytte ved BI-systemet. For det andet muliggør disse data, at vi kan undersøge, om brugerne er enige eller uenige med resultaterne fra det kvantitative studie. For det tredje kan kvalitative data bidrage til at forstå komplekse kvantitative resultater (Driscoll, Appiah-Yeboah, Salib, \& Rupert, 2007). Det er ofte anvendt at triangulere kvantitative data med kvalitative data. Kvantitative data kan tilvejebringe et bredere perspektiv, hvor kvalitative data kan tilvejebringe en dybde $\mathrm{i}$ forståelsen af de kvantitative data. Når de to metoder anvendes sammen, fører de til en bedre forståelse af det undersøgte (Seddon, Staples, Patnayakuni, \& Bowtell, 1999). Interviewguiden kan ses i (Gaardboe, 2018).

Der blev foretaget seks interviews og et gruppeinterview på universitetet. Alle interviews varede mellem 45 minutter og en time. Bagefter blev interviewene transskriberet og analyseret 
i Nvivo (Bazeley, 2007). Deduktiv kodning blev anvendt til at identificere eksempler på organisatorisk nytte. I de næste to afsnit vil resultaterne af det kvantitative og kvalitative studie blive præsenteret, hvorefter de to studier vil blive integreret.

\section{Resultater}

\section{Kvantitative resultater}

I dette studie er to modeller blevet analyseret med udgangspunkt i "IS Success Model" af DeLone og McLean (1992). Modellen er opdelt i to, da PLS ikke kan håndtere gensidige relationer (Hair m.fl., 2017). I den første model påvirkes brugertilfredsheden af brug. Og i den anden model påvirkes brug af brugertilfredsheden. Resultaterne viser, at determinationskoefficienten for individuel nytte er forklaret med 53,7 \% i begge modeller. I model 1 er brugertilfredshed forklaret med $45,1 \%$, medens det er $44,9 \%$ for model 2 . For brug er det henholdsvis $9,8 \% \mathrm{i}$ model 1 og $10,0 \%$ i model 2 .

Resultatet af modellens koefficienter og p-værdier er angivet i modellen nedenfor:

\begin{tabular}{|c|c|c|c|c|c|c|}
\hline & & Model 1 & & lodel 2 & & \\
\hline Hypotese & Relation & Koefficient & $\begin{array}{l}\text { P- } \\
\text { værdi }\end{array}$ & Koefficient & $\begin{array}{l}\text { P- } \\
\text { værdi }\end{array}$ & Konklusion \\
\hline H1 & $\begin{array}{l}\text { Systemkvalitet -> } \\
\text { Brugertilfredshed }\end{array}$ & 0,494 & 0,000 & 0,588 & 0,000 & Signifikant \\
\hline $\mathrm{H} 2$ & $\begin{array}{l}\text { Systemkvalitet -> } \\
\text { Brug }\end{array}$ & 0,324 & 0,000 & 0,289 & 0,000 & Signifikant \\
\hline H3 & $\begin{array}{l}\text { Informations- } \\
\text { kvalitet -> } \\
\text { Brugertilfredshed }\end{array}$ & 0,238 & 0,000 & 0,222 & 0,000 & Signifikant \\
\hline H4 & $\begin{array}{l}\text { Informations- } \\
\text { kvalitet -> Brug }\end{array}$ & 0,000 & 0,995 & $-0,039$ & 0,249 & $\begin{array}{l}\text { Ikke } \\
\text { signifikant }\end{array}$ \\
\hline H5a & $\begin{array}{l}\text { Brug -> } \\
\text { Brugertilfredshed }\end{array}$ & 0,058 & 0,203 & & & $\begin{array}{l}\text { Ikke } \\
\text { signifikant }\end{array}$ \\
\hline H5b & $\begin{array}{l}\text { Brugertilfredshed } \\
->\text { Brug }\end{array}$ & & & 0,116 & 0,007 & Signifikant \\
\hline H6 & $\begin{array}{l}\text { Brugertilfredshed } \\
\text {-> Individuel nytte }\end{array}$ & 0,720 & 0,000 & 0,756 & 0,000 & Signifikant \\
\hline H7 & $\begin{array}{l}\text { Brug -> Individuel } \\
\text { nytte }\end{array}$ & 0,052 & 0,188 & 0,060 & 0,002 & Signifikant \\
\hline
\end{tabular}

Tabel 2. Hypoteser, modellernes koefficienter og konklusion

I Figur 2 er hypoteserne i Tabel 2 illustreret. Systemkvalitet er positivt og signifikant relateret til både brugertilfredshed $(\mathrm{H} 1)$ og brug $(\mathrm{H} 2$ og $\mathrm{p}<0,001)$. Dette betyder, at jo højere systemkvalitet, des mere vil brugere bruge $\mathrm{BI}$ og have en høj tilfredshed. Der er en positiv og signifikant relation mellem informationskvalitet og brugertilfredshed ( $H 3$ og $p<0,001)$. Det vil sige, 
at jo højere informationskvalitet, des højere brugertilfredshed. Denne relation gør sig ikke gældende for relationen mellem informationskvalitet og brug (H4). Relationen mellem brugertilfredshed og brug $(\mathrm{H} 5 \mathrm{~b}$ og $\mathrm{p}<0.01)$ er også signifikant, men relationen mellem brug og brugertilfredshed kunne ikke bekræftes (H5a). Det vil sige, at jo højere brugertilfredshed, des mere brug af BI. Med henblik på relationen mellem brugertilfredshed og individuel nytte $(\mathrm{H} 6)$ er relationen også positiv og signifikant $(p<0,001)$. Dette gør sig også gældende for relationen mellem brug og individuel nytte $(H 7$ og $p<0,001)$. Det vil sige, at både brugertilfredshed og brug påvirker individuel nytte.

Relationerne mellem variablerne er interessante, men det er mindst lige så interessant at se, hvordan determinationskoefficienten bliver påvirket. Til dette må anvendes effektstørrelse $\left(f^{2}\right) . f^{2}$ på størrelserne $0,02,0,15$, og 0,35 er ofte betegnet som lille, medium og stor effekt. Systemkvalitet har en lille effekt på brug. Derimod har systemkvalitet en stor effekt på brugertilfredshed. Informationskvalitet har en lille effekt på brugertilfredshed, men ingen effekt på brug. Brugertilfredshed har en stor effekt på individuel nytte, hvorimod brug ikke har nogen effekt på individuel nytte.

\section{Kvalitative resultater}

Som tidligere nævnt, er brugerens individuelle nytte ikke nødvendigvis ensbetydende med, at organisationen får nytte af at anvende BI. Forudsætningen for, at BI skaber værdi i organisationen, er, at der bliver handlet på den information, som kommer fra systemet. Det vil sige, at såfremt der er information, der skal handles på, bliver det også gjort af de relevante beslutningstagere. I nogle tilfælde er Bl-bruger og beslutningstager den samme fysiske person, mens det i andre tilfælde er to forskellige personer. Det kan derfor godt være, at BI-brugeren ikke mener, at BI bidrager til organisatorisk nytte, mens beslutningstageren har en anden oplevelse. En sidste ting, som gør det vanskeligt at måle organisatorisk nytte, er, at der kan være en tidsforskel fra, at der bliver truffet en beslutning på baggrund af informationen fra $\mathrm{BI}$-systemet, til at effekterne af beslutningen er realiseret.

I forbindelse med de kvalitative interviews blev BI-brugerne spurgt, hvilken organisatorisk nytte, de mente, BI havde i organisationen i relation til forskellige interessenter. Gennemgående for alle interviewpersonerne var, at de i et eller andet omfang leverede informationen videre til andre beslutningstagere.

Ikke overraskende blev $\mathrm{Bl}$ anvendt til en traditionel form for ledelsesrapportering: typisk i form af kvartals- eller månedsrapportering relativt langt fra det universitetspædagogiske arbejde. En overraskende effekt af implementeringen af BI er imidlertid, at teknologien muliggør en større decentralisering af styringen - herunder økonomistyringen. Som en af interviewpersonerne udtrykker det:

Og det har gjort, at man har flyttet lidt tungere økonomiopgaver ned på institutterne. Der er mere, der er kommet ned til os ... Og det er helt sikkert, fordi vi kan selv hente data. Så nemt i [BI]. (Gaardboe, 2018).

Det vil sige, at BI har haft en betydning for, at der er blevet uddelegeret ansvar i organisationen. Fordelen ved dette er:

Ja, jeg ved jo, [medarbejderen] er gået ned i tid. Eller om han har fået en fjerdekvartalslønforhandling igennem. Det ved jeg. Men det ved de jo ikke altid nødvendigvis [centralt] (Gaardboe, 2018). 
En anden type af analyser, brugerne anvender BI til, er opslag efter data eller til at foretage ad hoc-analyser. En af brugerne forklarer det således:

Det er sådan en, hvordan kan det vaere, at forbrugsmønsteret afviger? Og afviger det meget i forhold til gennemsnittet over de sidste tre år? Det er ikke bare opslag, hvor jeg kan klikke fem gange, og jeg har oplysningen. Det vil voere noget, der kraever, at man selv dykker ned i det. Det er som regel tidskraevende opgaver. Men det er spaendende, og det giver jo også en faglighed (Gaardboe, 2018).

En anden type af opgaver, som brugerne fortæller om, er opgaver, hvor de af en beslutningstager er blevet anmodet om at søge efter faktuelle data i Bl. Karakteristisk for ad hocopgaverne er, at det ikke bare er rutineopgaver. Denne type opgaver stiller store faglige og tekniske krav til den medarbejder, som løser dem.

Det er ingen overraskelse, at $\mathrm{BI}$ anvendes til rapportering og ad hoc-analyser. En anden type af opgaver meget tættere på det universitetspædagogiske arbejde, BI anvendes til på universiteterne, er at følge op på de studerendes uddannelsesforløb. Denne nye type af brug er affødt af de forandringsindsatser, som vi beskrev i artiklens indledning. En af årsagerne til, at det er interessant at følge op på de studerendes forløb, er at sikre, at de ikke bliver forsinket $\mathrm{i}$ deres uddannelse, da det øger risikoen for frafald (viser nogle data. Øget pres på en studerende, som er blevet forsinket med henblik på et indhente forsinkelsen, kan formentlig også øge frafaldsrisikoen). Hvis det vurderes, at en studerende er frafaldstruet, målt på forskellige målepunkter, går en række procedurer i gang, som skal sikre opfølgning på dette. Dette har (muligvis) betydet, at nogle studerende nu fuldfører deres uddannelse, hvor de for få år siden ville være droppet ud. Det er interessant, fordi universitets indtægter fortrinsvis afgøres af, om de studerende gennemfører deres uddannelse, samt hvor hurtigt de bliver færdige. Som en studieleder forklarer:

... det er jo rimelig kritisk, at vi får lavet de rigtige prognoser for økonomien, fordi det styrer vores budget" (Gaardboe, 2018).

Et andet eksempel på opfølgning er, at studielederne følger op på de studerendes jobsituation efter endt uddannelse. I et konkret tilfælde fandt man ud af, at en stor andel af udenlandske studerende ikke fik job efter endt uddannelse. Her gik man ind og lavede nogle konkrete tiltag, eksempelvis at tilbyde danskundervisning eller hjælpe dem med at finde et relevant studiejob. Som en studieleder forklarer:

Og så har vi varet nede at undersøge, hvad skyldes det? Og det viser sig så, at det er noget med: Det er det, der er vigtigt for at få job. Det er studiejob undervejs, og lave projektsamarbejde med virksomheder. (Gaardboe, 2018)

Når et BI-system implementeres, er det ofte med en forventning om, at der er en økonomisk gevinst ved at bruge systemet. Som det fremgår af ovenstående, kan brugerne forklare deres brug af $\mathrm{BI}$ og den afledte organisatoriske nytte. Igennem alle interviews blev interviewpersonerne bedt om at forholde sig til den økonomiske gevinst af BI. Men det var gennemgående, at BI-brugerne ikke kunne fortælle, hvad implementering af BI havde betydet i monetære termer. Men de kunne fortælle, at det havde haft en stor betydning. Eksempelvis med henblik på de frafaldstruede studerende. I og med at de blev identificeret, og en dialog blev taget, kunne det i nogle tilfælde betyde, at de fik færdiggjort deres uddannelse. Fordi deres udfordringer blev afdækket, og der blev lagt en plan for, hvordan de kunne fuldføre deres uddannelse. 


\section{Diskussion}

I dette afsnit diskuteres artiklens resultater i relation til Bl's succes ud fra et slutbrugerperspektiv, og den organisatoriske nytte af BI på danske universiteter vurderes. Begge dele af diskussionen bevæger sig fra en bred palet af Bl-anvendelser til anvendelser tættere på det universitetspædagogiske arbejde. Hensigten er stadig, som nævnt i indledningen, at undersøge, hvad der skal til for, at man kan få succes med anvendelsen af BI i tilknytning til det universitetspædagogiske arbejde. Inden for Bl-forskningen eksisterer der et gap omkring, hvad der bidrager til Bl's succes i den offentlige sektor (Tona m.fl., 2012), herunder Bl's succes på universiteterne. Som nævnt indledningsvist, har der været et stigende eksternt og internt pres for en bedre styring, samtidig med at BI har nået et modenhedsstadie, som gør, at en stor del af universiteternes ansatte anvender teknologien. Den store kvantitative undersøgelse tilvejebringer information om, hvilke faktorer der er relateret til og vigtige for BI-succes.

For at få succes med BI er det vigtigt med en høj systemkvalitet. Det vil sige, at systemet skal være let at lære og let at bruge. Dette er i overensstemmelse med talrige undersøgelser, som eksempelvis (livari, 2005; Rai m.fl., 2002; Venkatesh \& Davis, 2000). Hvis systemet opfylder disse kriterier, så har det en stor effekt på brugernes tilfredshed og en mindre effekt på, om brugerne vil bruge systemet. En af årsagerne til, at systemkvalitet ikke har så stor en effekt på brug, er, at det i forvejen er obligatorisk for medarbejderen at anvende BI for at kunne fuldføre arbejdsopgaverne. Derfor er brug ikke så påvirkelig af de uafhængige variabler, som hvis BI havde været frivilligt at bruge. Det er også værd at bemærke, at casen i denne artikel anvender Qlikview, der af Gartner er vurderet til at være markedsleder inden for BI vurderet på 15 forskellige kapabiliteter, herunder brugervenlighed (Howson m.fl., 2018). Informationskvalitet er relateret til brugertilfredshed, men ikke til brug. Desuden kan der også måles en lille effekt på relationen mellem informationskvalitet og brugertilfredshed. Dette er også i overensstemmelse med flere studier (Petter m.fl., 2008). Ligesom med systemkvalitet anvender brugeren $\mathrm{Bl}$-systemet, hvis det er obligatorisk, og kvaliteten af den information, som ligger inde i systemet, har ikke så meget indflydelse på brugen. Det skal bemærkes, at brug er en adfærd, som kan påvirkes af ledelsen, idet ledelsen kan pålægge en medarbejder at arbejde med $\mathrm{Bl}$, mens brugertilfredshed er en attitude, som ikke i samme grad kan påvirkes af ledelsen. Selvom ledelsen kan pålægge medarbejderen at bruge IT-systemet, så viser resultaterne af denne undersøgelse, at brugen af BI er højere, hvis medarbejderen også har en højere brugertilfredshed. Dette kan også bekræftes i andre studier (Guimaraes \& Igbaria, 1997; McGil, Hobbs, \& Klobas, 2003; Rai m.fl., 2002). I studiet blev det også undersøgt, hvad der påvirkede BI-brugerens oplevelse af individuel nytte. Dette blev påvirket af brugertilfredsheden. Det vil sige, at jo mere tilfreds brugeren er, des mere nytte oplever den enkelte bruger. Det samme gør sig gældende med hensyn til brug. Jo mere brug, des mere oplevelse af individuel nytte. Disse resultater er også bekræftet i andre undersøgelser (Guimaraes \& Igbaria, 1997; livari, 2005; McGill \& Klobas, 2005; Rai m.fl., 2002). Opsummereret er alle variablerne i IS-succesmodellen vigtige, også på et universitet og i tilknytning til det universitetspædagogiske arbejde, men målt på effekt er de vigtigste relationer: relationen mellem systemkvalitet og brug og brugertilfredshed, mellem informationskvalitet og brugertilfredshed samt mellem brugertilfredshed og individuel nytte. Når der ikke er nogen stærk relation mellem oplevelse af systemkvalitet og oplevelse af individuel nytte, så er det naturligvis en anledning til yderligere undersøgelser med henblik på at afdække, hvorfor det forholder sig således. Når informationskvalitet samtidig ikke har særlig stor betydning for brugertilfredshed, så er det ligeledes anledning til fortsat forskning. En kritisk udlægning kunne være, at brugerne ikke oplever 
personlig nytte af en mere datafunderet tilgang til opgaveløsningen. En tilsvarende kritisk udlægning af svag sammenhæng mellem brugertilfredshed og oplevet informationskvalitet kunne være, at vi har at gøre med brugere, der løser en pålagt opgave med de data, der følger med opgaven uden at forholde sig kritisk til hverken opgave eller data. Forholder det sig således, er det problematisk for det universitetspædagogiske arbejde, for det kan antyde, at brugerne måske anvender BI til en opgave, de i værste fald ikke forstår relevansen af, og baserer sig på data, der kunne være fejlbehæftede, uden at forholde sig til det.

I relation til den organisatoriske nytte blev det identificeret, at der eksisterer to typer af brugere: systembrugere og informationsbrugere. Disse to brugertyper kan være identiske, men kan også være to fysisk forskellige medarbejdere. Dette er et vigtigt resultat i relation til BI på universiteterne, da systembrugernes behov for information kan være forskelligt fra informationsbrugerens behov. Et eksempel er opfølgning på nogle nøgletal i relation til de studerendes studieaktivitet, hvor systembrugeren kan vurdere den organisatoriske nytte som værende lav, mens informationsbrugeren kan vurdere det som høj nytte, at de frafaldstruede studerende bliver identificeret, og der bliver fulgt op på dem. Her kunne der således ligge en yderligere belysning af førnævnte mulige problemstillinger.

I den kvalitative undersøgelse identificerede vi tre typer af brug: traditionel ledelsesrapportering, ad hoc-analyser samt monitorering af forløb. Det karakteriserer de forskellige typer af brug, at de direkte eller indirekte er relateret til økonomi eller kvalitetsmål. Det interessante er imidlertid, at nøgletal i forhold til læring var fraværende i alle interviews til trods for, at der forskningsmæssigt er stor interesse for potentialet i learning analytics, og at der rundt omkring i verden pågår en del udviklingsarbejde. Derfor er det interessant, at selvom $\mathrm{BI}$ og "learning analytics" er relaterede teknologier, gør universitetet ikke brug af dette potentiale. En del af anvendelsen, som vi har kunnet identificere, peger ganske vist tilbage på samme brug af $\mathrm{Bl}$ og learning analytics med fokus på identifikation af frafaldstruede studerende, som Purdue University var med til at starte (Sclater, Peasgood \& Mullan 2016), men vi mangler stadig den undervisnings- og læringsintegrerede anvendelse af learning analytics, som Gašević et al (2015) efterlyser. I henhold til Ferguson (2012) vil det kræve fire ting: erfaringer fra forskningen inden for læring skal integreres, andre datasæt end de eksisterende skal integreres i Bl, værktøjet skal udvikles ud fra undervisernes perspektiv, og der skal udvikles nogle etiske retningslinjer. Vi har således i analysen set, at BI på eksisterende administrative data kan støtte driften af universitetsuddannelserne og i mindre omfang give direkte information til det pædagogiske arbejde i forhold til støtte af forebyggelse af frafald. Derudover mangler vi at se universitetet tage de næste skridt i forhold til (overvejelsen af) læringsintegration af dataanvendelsen.

Et andet potentiale i Bl, som ikke er udnyttet i relation til læring, er identifikationer af sammenhænge mellem data. I dag anvendes BI udelukkende til at rapportere på enkelte målinger, medens relationer mellem sammenhænge ikke afdækkes. For eksempel kan man ikke umiddelbart koble data om studerendes adgangsgrundlag med karakter- eller frafaldsdata. Begge dele kunne ellers indgå i overvejelser om, hvorvidt en uddannelse har det rigtige optagelsessystem, eller det kunne bruges til at identificere studerende, som er potentielt frafaldstruede, på et tidligere tidspunkt.

Brugen af data i uddannelserne rejser, som tidligere antydet, også nye etiske overvejelser. Studerende og undervisere producerer masser af data, som for eksempel kan bruges til at identificere studerende, som er mere frafaldstruede end andre. Men hvis vi samler data og 
tillader, at de samkøres med henblik på den type analyser, så er det helt store spørgsmål, hvem der skal have adgang til resultatet? Det kan være stigmatiserende for en studerende at få betegnelsen "frafaldstruet". Det er også ressourcetungt for universitetet at iværksætte særlige indsatser for de studerende, der er mest frafaldstruede. Ressourcer, der bruges på særligt frafaldstruede, kan ikke bruges på andre indsatser for den brede gruppe af studerende eller for særligt talentfulde studerende.

\section{Konklusion}

I denne artikel undersøges, hvilke faktorer der bidrager til Bl-succes samt den organisatoriske nytte af værktøjet - i begge tilfælde med særligt fokus på forhold med relevans for det universitetspædagogiske arbejde. Universitetssektoren har undergået store forandringer det sidste årti, og derfor er det relevant at undersøge Bl's succes, idet værktøjet bruges til at træffe beslutninger på baggrund af nøgletal inden for kvalitet og økonomi.

Ved hjælp af PLS kan det konkluderes, at jo højere systemkvalitet, des højere brugertilfredshed og brug. I relation til informationskvaliteten kan det konkluderes, at jo bedre informationskvalitet, des højere brugertilfredshed. Der er også en positiv relation mellem brugertilfredshed og brug. Succesmålet individuel nytte påvirkes af både brugertilfredshed og brug. Det betyder, at Bl's succes på universiteterne skal forstås ud fra flere variabler og relationerne mellem disse. Den største effekt har systemkvalitet på brugertilfredshed, og denne variabel har også en stor effekt på individuel nytte. Systemkvalitet har også en lille effekt på brug, men brug har ikke effekt på individuel nytte. Informationskvalitet har kun en lille effekt på brugertilfredshed, hvilket naturligvis kan undre lidt og inspirere til yderligere undersøgelser.

I forhold til det universitetspædagogiske arbejde må det nøje overvejes, hvilke konsekvenser disse sammenhænge har. Det er forventeligt, at oplevelse af systemkvalitet kan kobles med brugertilfredshed. Det synes mere kritisk, at oplevet systemkvalitet ikke synes at have nogen betydning for oplevelsen af individuel nytte. En mulig hypotese er, at BI-brugerne har svært ved at vurdere nytten af deres BI-brug i forhold til eget arbejde. Denne kritiske hypotese kan måske også understøttes af, at informationskvaliteten kun i ringe grad påvirker brugertilfredsheden. Måske har vi målt på et system, hvor alle brugere altid og med rette kan have tillid til informationskvaliteten, men det er næppe tilfældet. Forhåbentligt er der ikke tale om, at data er blevet en fjern sandhed, som brugerne altid tager for givet og hverken forholder sig kritisk til eller ser nogen særlig nytte af. I forhold til det universitetspædagogiske arbejde kan vi således frygte, at data er afstandsskabende og i værste fald fremmedgørende, så medarbejdere, der løser en universitetspædagogisk opgave helt eller delvist, har mistet forståelsen af egen rolle og eget bidrag. Yderligere forskning er nødvendig for at undersøge disse hypoteser. Hvis det skulle vise sig korrekt, at data-brugerne faktisk har svært ved at se nytten af data og svært ved at forholde sig kritisk til dem, så skal det også undersøges, hvordan databrug kan få den rette plads i det universitetspædagogiske arbejde, uanset om løsningen er, at organisationen skal blive bedre til at anvende data, eller om vi skal anvende data langt mindre.

I relation til den organisatoriske nytte blev det identificeret, at der eksisterer to typer af brugere: systembrugere og informationsbrugere. Disse to brugertyper kan være identiske, men kan også være to fysisk forskellige medarbejdere. Desuden kan det konkluderes, at brugerne typisk anvender BI til rapportering, ad hoc-rapportering og opfølgning på forløb. Måske ligger noget af forklaringen på, at oplevelsen af personlig nytte er svag, allerede her. Hvis værktøjet vedrører andres arbejde eller andres studieforløb, placeres nytten et andet sted, så at sige. 
Men det potentiale, der ifølge andre forskere ligger $\mathrm{i}$ at bruge BI til learning analytics, er uforløst. Fremtidig forskning skal vise, hvordan der bedre kan bygges broer mellem data fra traditionel $\mathrm{BI}$ og de nyere udviklinger inden for learning analytics, da der i forhold til uddannelsesinstitutioner er klare fællestræk mellem de to typer af systemer og overlap mellem de data, der findes i Bl-systemet i den aktuelle case, og de data-typer, der kan være relevante for learning analytics.

Med denne artikel har vi også præsenteret en model for evaluering af BI og learning analytics-redskaber, der kan bruges til at evaluere anvendeligheden af de kommende udviklingsskridt for learning analytics i universiteter og universitetsuddannelser.

\section{Referencer}

Bailey, J. E., \& Pearson, S. W. (1983). Development of a tool for measuring and analyzing computer user satisfaction. Management science, 29(5), 530-545.

Bazeley, P. (2007). Qualitative Data Analysis with NVivo. London: Sage Publications Ltd.

Brynjolfsson, E., Hitt, L. M., \& Kim, H. H. (2011). Strength in Numbers: How Does Data-Driven Decisionmaking Affect Firm Performance? SSRN Electronic Journal. https://doi.org/10.2139/ssrn.1819486

Chen, I. J. (2001). Planning for ERP systems: analysis and future trend. Business process management journal, 7(5), 374-386.

Choudrie, J. (2005). Investigating the Research Approaches for Examining Technology Adoption Issues. Journal of Research Practice, 1(1), D1.

DeLone, W. H., \& McLean, E. R. (1992). Information Systems Success: The Quest for the Dependent Variable. Information Systems Research, 3(1), 60-95. https://doi.org/10.1287/isre.3.1.60

Dillman, D. A., Smyth, J. D., \& Christian, L. M. (2014). Internet, phone, mail, and mixed-mode surveys: the tailored design method (4th edition). Hoboken: Wiley.

Driscoll, D. L., Appiah-Yeboah, A., Salib, P., \& Rupert, D. J. (2007). Merging qualitative and quantitative data in mixed methods research: How to and why not. Ecological and Environmental Anthropology (University of Georgia), 18.

Ferguson, R. (2012). Learning analytics: drivers, developments and challenges. International Journal of Technology Enhanced Learning, 4(5/6), 304. https://doi.org/10.1504/IJTEL.2012.051816

Fornell, C., \& Larcker, D. F. (1981). Evaluating structural equation models with unobservable variables and measurement error. Journal of marketing research, 39-50.

Gaardboe, R. (2018). Kritiske succesfaktorer for Business Intelligence. Aalborg University Press. https://doi.org/10.5278/vbn.phd.hum.00088

Gaardboe, R., \& Svarre, T. (2018). Business Intelligence Success Factors: A literature review. Journal of Information Technology Management, 29(1), 1-15. 
Gaardboe, R., Svarre, T., \& Kanstrup, A. M. (2015). Characteristics of business intelligence and big data in e-government: Preliminary findings. Innovation and the Public Sector, 109115. https://doi.org/10.3233/978-1-61499-570-8-109

Guimaraes, T., \& Igbaria, M. (1997). Client/server system success: Exploring the human side. Decision Sciences, 28(4), 851-876.

Hair, J., Hult, T., Ringle, C., \& Sarstedt, M. (2017). A primer on partial least squares structural equation modeling (PLS-SEM). Thousand Oaks, CA: SAGE Publications, Inc.

Howson, C., Sallam, R. L., Richardson, J. L., Tapadinhas, J., Idoline, C. J., \& Woodward, A. (2018). Magic Quadrant for Analytics and Business Intelligence Platforms. Hentet 20. august 2015, fra https://www.gartner.com/doc/3861464/magic-quadrant-analytics-businessintelligence

livari, J. (2005). An empirical test of the DeLone-McLean model of information system success. ACM SIGMIS Database, 36(2), 8-27. https://doi.org/10.1145/1066149.1066152

McGil, T., Hobbs, V., \& Klobas, J. (2003). User-Developed Applications and Information Systems Success: A Test of DeLone and McLean's Model. Information Resources Management Journal, 16(1), 24-45.

McGill, T. J., \& Klobas, J. E. (2005). The role of spreadsheet knowledge in user-developed application success. Decision Support Systems, 39(3), 355-369.

https://doi.org/10.1016/j.dss.2004.01.002

Nakayama, M., Olbrich, S., \& Sutcliffe, N. (2017). Changing with Grassroots Business Intelligence at a Large Global Manufacturing Firm. I B. Johansson, C. Møller, A. Chaudhuri, \& F. Sudzina (Red.), Perspectives in Business Informatics Research (Bd. 295, s. 148-156). Cham: Springer International Publishing. https://doi.org/10.1007/978-3-319-649306_11

Olszak, C. M., \& Ziemba, E. (2012). Critical success factors for implementing business intelligence systems in small and medium enterprises on the example of upper Silesia, Poland. Interdisciplinary Journal of Information, Knowledge, and Management, 7(2), 129150.

Pattavina, A. (Red.). (2005). Information technology and the criminal justice system. Thousand Oaks, Calif: Sage Publications.

Petter, S., DeLone, W., \& McLean, E. (2008). Measuring information systems success: models, dimensions, measures, and interrelationships. European Journal of Information Systems, 17(3), 236-263. https://doi.org/10.1057/ejis.2008.15

Petter, S., DeLone, W., \& McLean, E. R. (2013). Information Systems Success: The Quest for the Independent Variables. Journal of Management Information Systems, 29(4), 7-62. https://doi.org/10.2753/MIS0742-1222290401

Prybutok, V. R., Zhang, X., \& Ryan, S. D. (2008). Evaluating leadership, IT quality, and net benefits in an e-government environment. Information \& Management, 45(3), 143-152.

Rai, A., Lang, S. S., \& Welker, R. B. (2002). Assessing the Validity of IS Success Models: An Empirical Test and Theoretical Analysis. Information Systems Research, 13(1), 50-69. 
Regeringen. (2015). Sammen for fremtiden. Hentet 24. august 2018, fra http://stm.dk/multimedia/Sammen_for_fremtiden_-_Regeringsgrundlag.pdf

Rosacker, K. M., \& Olson, D. L. (2008). Public sector information system critical success factors. Transforming Government: People, Process and Policy, 2(1), 60-70. https://doi.org/10.1108/17506160810862955

Seddon, P. B. (1997). A Respecification and Extension of the DeLone and McLean Model of IS Success. Information Systems Research, 8(3), 240-253. https://doi.org/10.1287/isre.8.3.240

Seddon, P. B., Staples, S., Patnayakuni, R., \& Bowtell, M. (1999). Dimensions of information systems success. Communications of the AIS, 2(3es), 5.

Sclater, N., Peasgood, A. \& Mullan, J. (2016). Learning Analytics in Higher education: A review of UK and International Practice. Jisc.

Tona, O., Carlsson, S. A., \& Eom, S. (2012). An empirical test of Delone and McLean's information system success model in a public organization. I 18th Americas Conference on Information Systems 2012, AMCIS 2012 (s. 1374-1382).

Trieu, V.-H. (2017). Getting value from Business Intelligence systems: A review and research agenda. Decision Support Systems, 93, 111-124. https://doi.org/10.1016/j.dss.2016.09.019

Uddannelses- og forskningsministeriet. (2018). Fremdriftsreformen. Hentet 24. august 2018, fra https://ufm.dk/uddannelse/indsatsomrader/fremdriftsreformen

Venkatesh, V., \& Davis, F. D. (2000). A theoretical extension of the technology acceptance model: Four longitudinal field studies. Management science, 46(2), 186-204.

VK Regeringen II. (2005). Nye mål - regeringsgrundlaget [http://www.stm.dk/publikationer/reggrund05/index.htm]. Hentet 24. august 2018, fra http://www.stm.dk/publikationer/reggrund05/index.htm

Wixom, B., \& Watson, H. (2010). The BI-Based Organization: International Journal of Business Intelligence Research, 1(1), 13-28. https://doi.org/10.4018/jbir.2010071702 